RESEARCH ARTICLE

\title{
Effects of organic, inorganic and organo-mineral fertilizer on the growth, yield and nutrient composition of Corchorus Olitorious $(L)$
}

\author{
A. Ayinla ${ }^{1 . *}$, I. A. Alagbe ${ }^{1}$, B. U. Olayinka ${ }^{1}$, A. R. Lawal ${ }^{1}$, O. O. Aboyeji ${ }^{2}$ and E. O. Etejere ${ }^{1}$ \\ ${ }^{1}$ Department of Plant Biology, University of Ilorin, Ilorin, Nigeria \\ ${ }^{2}$ Department of Biology, Kwara State College of Education Technical, Lafiaji, Nigeria
}

Received:11/04/2017; Accepted:04/02/2018

\begin{abstract}
Corchorus olitorius (L.) is an important leafy vegetable known for its rich source of several nutrients and dietary fibre in Africa, Asia and some parts of America. One major limitation of cultivating Corchorus olitorius in the tropics is inadequate soil fertility. Fertilizer application is an integral part of the vegetable cultivation due to low soil productivity. The study therefore aims at evaluating the effects of organic, inorganic and organo-mineral fertilizer at different concertation on the growth, yield and nutrient composition of Corchorus olitorious. The experimental setup followed a complete randomized block design with three replicates. Treatments include control, 1,000 $\mathrm{kgha}^{-1}$ sole poultry manure (PM), 2,000 $\mathrm{kgha}^{-1}$ sole PM, $200 \mathrm{kgha}^{-1}$ sole NPK, 400 $\mathrm{kgha}^{-1}$ sole NPK, $600 \mathrm{kgha}^{-1}$ sole NPK, 1,000 kgha ${ }^{-1} \mathrm{PM}+200$ kgha $^{-1}$ NPK, 1,000 kgha ${ }^{-1} \mathrm{PM}+400 \mathrm{kgha}^{-1} \mathrm{NPK}, 1,000 \mathrm{kgha}^{-1}$ $\mathrm{PM}+600 \mathrm{kgha}^{-1} \mathrm{NPK}, 2,000 \mathrm{kgha}^{-1} \mathrm{PM}+200 \mathrm{~kg} / \mathrm{ha}$ NPK, 2,000 $\mathrm{kgha}^{-1} \mathrm{PM}+400 \mathrm{kgha}^{-1} \mathrm{NPK}$ and 2,000 $\mathrm{kgha}^{-1} \mathrm{PM}+600 \mathrm{kgha}^{-1} \mathrm{NPK}$ fertilizer combinations. The growth, yield and nutrient composition of C. olitorious plants were significantly enhanced in all fertilizer treated plots in comparison to the control. Significantly $(p<0.05)$ higher growth parameters, yield and nutrient composition were recorded in the plots treated with combined application of both fertilizers at 2,000 $\mathrm{kgha}^{-1} \mathrm{PM}+400 \mathrm{kgha}^{-1} \mathrm{NPK}$ and 2,000 $\mathrm{kgha}^{-1} \mathrm{PM}+600 \mathrm{kgha}^{-1} \mathrm{NPK}$ when compared to other application combinations. This study affirms that the combined application of organic and inorganic fertilizer as a soil amendment could enhance growth, yield, and nutrient composition of $C$. olitorious in comparison with sole application of either fertilizers.
\end{abstract}

Keywords: Corchorus olitorious, fertilizer, growth, nutrient composition

\section{INTRODUCTION}

Corchorus olitorius known commonly as 'fruited jute', 'bush okra' or 'jute mallow' is a common tropical leafy vegetable found in Africa, Asia and some parts of the Middle East and Latin America (Odofin et al., 2011). It has succulent leaves which soften rapidly with cooking, and thickens into a viscous mucilaginous soup which can be eaten with starchy foods (Adediran et al., 2015). On average, $100 \mathrm{~g}$ of edible leaves of Corchorus olitorius contains 85-87g water, 5-6 g protein, $0.7 \mathrm{~g}$ oil, $5 \mathrm{~g}$ carbohydrate, 1-5 g fibre, $250-266 \mathrm{Mg}$ and $\mathrm{Ca}, 4-8 \mathrm{mg}$ iron, $3000 \mathrm{iu}$ vitamin $\mathrm{A}, 0.1 \mathrm{mg}$ thiamine, $0.3 \mathrm{mg}$ riboflavin, $1.5 \mathrm{mg}$ nicotinamide and 53-100 mg ascorbic acid (Aluko et al., 2014). One of the major challenges of crop production in the tropics is inadequate soil fertility which results from soil erosion, denitrification, overgrazing, deforestation and other human activities (Adediran et al., 2015). Deficiency or inadequate soil nutrients for proper plant nourishment is evident in poor yield and yield quality (Aluko et al., 2014). Attempts made by agriculturists to meet the demands of the ever-growing population by application of fertilizer to replace the lost nutrient in the soil (Adediran et al., 2015). Inorganic fertilizers have been used to ameliorate the soil nutrient level (Adejoro, 2011; Law-Ogbomo and Remison, 2007; Masarirambi et al. 2011) owing to their rapidly release of nutrients to be taken up by plants and also due to their easy handling (Adediran et al., 2015). However, inorganic fertilizers have several limitations including high purchase costs, scarcity, pollution of ground water and deterioration of soil physical properties by depleting the soil organic matter on account of continuous usage over time (Ghoneim and El-Araby, 2003). Several studies have confirmed the use of organic manure as a better alternative to chemical fertilizer (Abd El-Megeed et al., 2000; Mahmoud et al, 2000; Mohamed and Gabr, 2002). This is because it is cheap and affordable, eco-friendly and it had a profound effect on the activity of soil microflora as well as soil physico-chemical properties (Ghoneim and ElAraby, 2003). Organic fertilizers also have their limitations including high risk of infection, high cost of transportation and labour on account of its bulkiness as well as a slow release of nutrients for plant uptake (Adediran et al., 2015) Studies have also confirmed that the combination of organic and inorganic fertilizer in a sustainable ratio as a strategy to combat low available soil nutrients in the tropics (LawOgbomo and Osaigbovo, 2016). However, information comparing the three fertilizer application forms in the cultivation of an important leafy vegetable like Corchorus olitorious is scanty (Ghoneim and El-Araby, 2003). The aim of this study is to evaluate the effect of organic, inorganic and organo-mineral fertilizer applications on the vegetative growth, productivity and nutrient constituents of Corchorus olitorious.

\section{MATERIALS AND METHOD}

\section{Source of Materials}

Seeds of Corchorus olitorious ('oniyaya' cultivar) were obtained from National Horticultural Research Institute (NIHORT), Ibadan, Nigeria. Barnyard manure was 
obtained from a local poultry establishment at Tanke OkeOdo, Ilorin, Nigeria. Inorganic fertilizer (NPK 15-15-15) was procured from an Agro-chemical shop in Ilorin.

\section{Analysis of Soil and Organic Manure}

Air-dried and pulverized poultry manure as well as a composite soil sample $(0-30 \mathrm{~cm}$ depth) taken from the site were both analysed for physio-chemical properties using standard laboratory procedures outlined by Mylavapus and Kennelley (2002). The soil particle size distribution was determined by Hydrometer method. Organic carbon content was determined by modified wet oxidation method of Walkey and Black (1945). The soil pH was measured with ta $\mathrm{pH}$ meter (Oakton ${ }^{\mathrm{TM}}$ water proof $\mathrm{pH} 450$ portable meter) in 1:1 soil-water ratio suspension. Total nitrogen was determined by a semi-micro Kjedahl digestion distillation method (Bermer and Mulvalcy, 1982) while, the available phosphorous was determined by L-ascorbic method (Bray and Kurtz, 1945). The total exchangeable acidity was assessed by method described by Maclean (1982), while the cation exchange capacity (CEC) was determined via ammonium saturation of exchange site and analysis of saturated ammonium using an ammonium ion-selective electrode. (Soil and Plant Analysis Council, 2000). Similarly, exchangeable $\mathrm{K}, \mathrm{Ca}, \mathrm{Mg}, \mathrm{Na}$ were determined using the $\mathrm{KCl}$ method and the percentage base saturation was calculated as the sum of exchangeable bases divided by the cation exchange capacity and multiplied by 100 .

\section{Experimental Design and Treatments}

The experimental layout followed a complete randomized block design with three replications per treatment. The dimension of the gross plot measured $10 \mathrm{~m} \times 8 \mathrm{~m}$, while that of the net plots is $2 \mathrm{~m} \times 2 \mathrm{~m}$. Each net plot was separated from each other by $0.5 \mathrm{~m}$. Plant spacing on each of the net plots was $0.3 \mathrm{~m} \times 0.3 \mathrm{~m}$. Treatments include control, 1,000 $\mathrm{kgha}^{-1}$ sole poultry manure (PM), 2,000 $\mathrm{kgha}^{-1}$ sole PM, $200 \mathrm{kgha}^{-1}$ sole NPK, $400 \mathrm{kgha}^{-1}$ sole NPK, $600 \mathrm{kgha}^{-1}$ sole NPK, 1,000 kgha-1 PM+200 kgha-1 NPK, 1,000 kgha-1 $\mathrm{PM}+400 \mathrm{kgha}^{-1} \mathrm{NPK}, 10,000 \mathrm{kgha}^{-1} \mathrm{PM}+600 \mathrm{kgha}^{-1} \mathrm{NPK}$, 2,000 $\mathrm{kgha}^{-1} \mathrm{PM}+200 \mathrm{~kg} / \mathrm{ha}$ NPK, 20,000 kgha-1 PM+400 $\mathrm{kgha}^{-1} \mathrm{NPK}$ and 2,000 $\mathrm{kgha}^{-1} \mathrm{PM}+600 \mathrm{kgha}^{-1} \mathrm{NPK}$ fertilizer combinations

The experimental plots were manually cleared and plant beds were prepared. The seeds dormancy of Corchorus olitorious $\mathrm{L}$ was broken by steeping in hot water between 80- $97^{\circ} \mathrm{C}$ for 5 seconds (Tolorunse et al., 2015) to ensure rapid and uniform germination of seeds. Thereafter, seeds were sown at $0.3 \mathrm{~m} \times 0.3 \mathrm{~m}$ using drilling method to give room for hand-weeding operations. Plots were handweeded at intervals of 2 weeks throughout the study period. Harvesting was done at 8 weeks (56 days) after planting.

\section{Fertilizer Application}

Sole organic fertilizer (poultry manure) at the rates of 1,000 $\mathrm{kgha}^{-1}$ and 2,000 $\mathrm{kgha}^{-1}$ poultry manure were uniformly spread on the plots and lightly incorporated into the soil with the use of a hoe. Sole inorganic fertilizer (NPK 15-1515 ) containing $1.10 \%$ sulphur, $0.02 \%$ boron, $0.05 \%$ copper,
$0.1 \%$ iron, $0.05 \%$ manganese, $0.001 \%$ molybdenum and $0.05 \%$ zinc was also applied by ringing them around the plant at the rate of $200 \mathrm{kgha}^{-1}, 400 \mathrm{kgha}^{-1}$ and $600 \mathrm{kgha}^{-1}$ while organomineral fertilizer was applied at the rates of $1000 \mathrm{kgha}^{-1}+200 \mathrm{kgha}^{-1}, 1,000 \mathrm{kgha}^{-1}+400 \mathrm{kgha}^{-1}, 1,000$ $\mathrm{kgha}^{-1}+600 \mathrm{kgha}^{-1}, 2,000 \mathrm{kgha}^{-1}+200 \mathrm{kgha}^{-1}, 2,000 \mathrm{kgha}^{-1}$ $+400 \mathrm{kgha}^{-1}$ and 2,000 $\mathrm{kgha}^{-1}+600 \mathrm{kgha}^{-1}$ poultry manure and NPK 15:15:15 combinations, respectively

\section{Data Collection}

The vegetative parameters such as plant height, stem girth, number of leaves and leaf area using CI-202 portable leaf area meter (CID Bio Science Inc) were recorded at 28, 42 and 56 days after planting. At harvest (56 days after planting), above-ground fresh and dry weight were determined. Yield components such as number of pods per plant, pod weight (fresh and dry) were also determined. Harvest was done at 56 days after planting by cutting at the soil level, and the fresh plants were weighed for total biomass using a Kern electronic weighing balance ABT 120-4M. The plant material obtained was oven dried at $80^{\circ} \mathrm{C}$ for 24 hours before taking the dry weight measurements.

\section{Proximate and Mineral Analysis}

The leaf samples were analysed for proximate composition (moisture, ash, crude fats, protein, crude fibre and carbohydrate) were determined according to the standard method described by AOAC (2010). Nitrogen content was deduced by the micro kjedal method (AOAC, 2010) while potassium and phosphorus contents were measured using an Atomic Absorption Spectrophotometer (PG 990) after digestion with nitric acid. All the samples were analysed in triplicate and the mean values were recorded.

\section{Data Analysis}

The data were subjected to analysis of variance (ANOVA) using Statistical Package of Social Science (SPSS version 20.0). Means were separated using Duncan multiple range test at $5 \%$ probability level.

\section{RESULTS AND DISCUSSION}

\section{Soil Parameters}

The soil is slightly alkaline ( $\mathrm{pH}$ of 7.5 ) with $82.25,10.09$, and $7.66 \%$ sand, silt and clay respectively with a textural class of sand (Table 1). The soil organic carbon, cation exchange capacity and base saturation are 1.22\%, 2.95\% and $27.45 \%$ respectively (Table 1 ). All other inherent mineral nutrients except exchangeable magnesium and organic matter were below the critical levels as suggested by Ibude et al. (1988) and Law-Ogbomo and Osaigbovo (2016). This result aligns with Akanbi and Togun (2002), who reported that most African soils are impoverished due to weathering, leaching and intensive cultivation. Similar result was also obtained by Law-Ogbomo and Osaigbovo (2016) in a study conducted on to evaluate of the use of food waste compost and inorganic fertilizer on the growth and yield of Corchorus olitorius in a humid ultisol of southwestern Nigeria. 
Table 1: Analysis of the experimental field soil.

\begin{tabular}{lcc}
\hline \multicolumn{1}{c}{ Soil parameters } & Value & Critical Value* \\
\cline { 2 - 3 } $\mathrm{pH}$ & 7.5 & -- \\
Total Nitrogen $(\%)$ & 0.3 & 0.15 \\
Organic Carbon $(\%)$ & 1.12 & --- \\
Organic matter $(\%)$ & 2.11 & 2.0 \\
Sand $(\%)$ & 82.25 & --- \\
Silt $(\%)$ & 11.09 & --- \\
Clay (\%) & 7.66 & --- \\
Available Phosphorus $(\mathrm{mg} / \mathrm{kg})$ & 1.50 & 8.50 \\
Exchangeable $\mathrm{K}(\mathrm{cmol} / \mathrm{kg})$ & 0.04 & 0.16 \\
Exchangeable $\mathrm{Ca}(\mathrm{cmol} / \mathrm{kg})$ & 0.08 & 1.50 \\
Exchangeable $\mathrm{Mg}(\mathrm{cmol} / \mathrm{kg})$ & 0.68 & 0.28 \\
Exchangeable $\mathrm{Na}(\mathrm{cmol} / \mathrm{kg})$ & 0.25 & --- \\
Acidity & 1.96 & --- \\
C.E.C. $(\mathrm{cmol} / \mathrm{kg})$ & 2.95 & --- \\
Base saturation $(\%)$ & 27.45 & --- \\
\hline
\end{tabular}

*Ibedu et al., (1988); Law-ogbomo and Osaigboyo, (2016).

Table 2: Analysis of organic fertilizer used for the experiment.

\begin{tabular}{lc}
\hline \multicolumn{1}{c}{ Treatment } & Value \\
\hline $\mathrm{pH}$ & 7.2 \\
Total Nitrogen (\%) & 1.37 \\
Organic Carbon (\%) & 22.80 \\
Organic Matter $(\%)$ & 36.62 \\
Available Phosphorus $(\mathrm{mg} / \mathrm{kg})$ & 0.92 \\
$\mathrm{~K}(\mathrm{cmol} / \mathrm{kg})$ & 0.35 \\
$\mathrm{Ca}(\mathrm{cmol} / \mathrm{kg})$ & 6.04 \\
$\mathrm{Mg}(\mathrm{cmol} / \mathrm{kg})$ & 1.40 \\
$\mathrm{Na}(\mathrm{cmol} / \mathrm{kg})$ & 0.17 \\
\hline
\end{tabular}

\section{Chemical Composition of Organic Fertilizer}

The organic manure contained organic carbon, organic matter, nitrogen, potassium, calcium and magnesium contents of $22.8 \%, 36.62 \%, 1.37 \%, 0.35 \mathrm{cmol} / \mathrm{kg}, 6.04$ $\mathrm{cmol} / \mathrm{kg}$ and $1.40 \mathrm{cmol} / \mathrm{kg}$ respectively (Table 2). The result of the organic manure analysis depicts a considerably higher nutrient status when compared to that of the field soil. This is an indication of the organic manure's capability of improving the soil nutrient status if allowed to mineralize for the release of its nutrients (Law-Ogbomo and Osaigbovo, 2016). A similar result was obtained by Adediran et al. (2015) in a study on the effect of different nutrient sources on the growth and yield of Corchorus olitorious.

\section{Plant Growth Attributes}

All morphological growth characters of Corchorus olitorious plants considered were significantly affected by the fertilizer treatments at $\mathrm{p}<0.05$ (Tables 3). Plant height, number of leaves, and leaf area of Corchorus olitorious were significantly higher in plots treated with $2000 \mathrm{~kg}$ /ha poultry manure $+600 \mathrm{~kg} / \mathrm{ha}$ NPK compared to all other treatments considered at all sampling stages (Table 3). This was followed by plots treated with different concentrations of sole NPK fertilizer $\left(\mathrm{T}_{3}, \mathrm{~T}_{4}\right.$ and $\left.\mathrm{T}_{5}\right)$ which were significantly higher than those treated with sole poultry manure at the initial stage of the study i.e. 28 and 42 days after planting.
Thereafter, Plots treated with different concentrations of sole poultry manure became significantly higher than those of sole NPK fertilizer at 56 days after planting. Significantly lowest plant height, number of leaves, stem girth and leaf area were recorded in the control at all sampling stages (Table 3 and 4). Significantly the highest growth parameters obtained in plots treated with $2000 \mathrm{~kg} /$ ha poultry manure + $600 \mathrm{~kg} / \mathrm{ha}$ NPK compared to all other treatments considered could be due to the combined effect of both fertilizer forms as suggested by Ullah et al. (2008) in a study to evaluate the effects of organic and chemical fertilizers on the growth and yield of Solanum melongena. The combined application of poultry and inorganic fertilizers has been shown to integrate the attributes of sole organic and sole inorganic fertilizers (Okunola et al., 2011). Significantly higher growth parameters obtained in plants treated with sole NPK fertilizer in comparison to those treated with sole poultry manure during the initial stage of study could be attributed to the ready availability of nutrients in contrary to the slow release of nutrients through the decomposition of poultry manure as reported by Mogapi et al. (2013). Significantly higher growth parameters obtained in sole poultry manure treatments when compared to sole NPK $15: 15: 15$ at 56 days after planting could be due to the fact that the nitrogen present in poultry manure is released slowly and consistently to meet the growth requirement of the plant throughout its growth stages unlike inorganic nitrogen source that is easily lost soon after application 
(Adediran et al, 2015). Poultry manure has been reported to have a greater ability to conserve nitrogen when compared to NPK 15:15:15 which easily lost after application through rapid crop removal, run-off, volatilization, leaching and/or denitrification. (Olaniyi et al., 2010) As expected, the poor plant growth was reported in control plots as plants suffer due to the inherently poor soils. The results are similar to the study carried out by Mogapi et al. (2013) to check the effect of poultry manure and commercial fertilizer on growth of Corchorus olitorius. Significantly highest fresh and dry weight was recorded in plots treated with a combination of $20000 \mathrm{~kg} / \mathrm{ha}$ poultry manure and $600 \mathrm{~kg} /$ ha NPK with values of $29.49 \mathrm{~g}$ and $7.95 \mathrm{~g}$ respectively when compared to all other treatments. This was followed by the various combined application of poultry and inorganic manure $(1000 \mathrm{~kg} / \mathrm{ha}$ organic fertilizer $+200 \mathrm{Kg} /$ ha inorganic fertilizer, $1000 \mathrm{~kg} / \mathrm{ha}$ organic fertilizer +400 $\mathrm{Kg} /$ ha inorganic fertilizer, $1000 \mathrm{~kg} / \mathrm{ha}$ organic fertilizer $+600 \mathrm{Kg} / \mathrm{ha}$ inorganic fertilizer, and $2000 \mathrm{~kg} / \mathrm{ha}$ organic fertilizer $+200 \mathrm{Kg} /$ ha inorganic fertilizer) all of which were significantly higher $(\mathrm{p}<0.05)$ compared to sole application of both fertilizers and the control. Fresh and dry biomass were significantly higer in sole organic manure treated plants when compared to the inorganic and the control while significantly lowest fresh and dry weight was recorded in the control plots (Table 4). Significantly higher fresh and dry biomass accumulation in the organomineral fertilizer treatments obtained in this study when compared to the sole application of either fertilizers and the control is an indication that organo-mineral fertilizer is a better alternative to the sole application of either fertilizers. The combinations of organic and mineral fertilizer have been reported to perform better on the yield of tomato, maize, and Solanum macrocarpon than sole application of either fertilizers.(Akanni et al., 2011; Ayeni, 2008; Ogunlade et al., 2011). . Significantly higher fresh and dry biomass in sole organic manure application compared to sole inorganic fertilizer could be due to better nutrient uptake in organic manure when compared to inorganic fertilizer (Mishra and Ganesh, 2005). Organic manure has been reported to improve plant nutrient uptake by acting as a buffering agent against undesirable $\mathrm{pH}$ fluctuations and by improving soil water availability through retention and aeration which ultimately contributes to better nutrients utilization by the crop (Adediran, 2015). This was evident in the higher fresh and dry matter accumulation of sole organic manure treated plot compared to sole inorganic manure treated plots and the control. The least fresh and dry weight of plants in the control plots is a reflection of the soil nutrients deficit as evident in the soil physicochemical properties. The result is in tandem with Aluko et al., (2014) in a study on the effect of organic and inorganic fertilizer on the growth and yield of Corchorus olitorius. The fresh and dry pod weight as well as pod number followed similar trend as the fresh and dry biomass (Table 5). This could be due to reasons adduced to fresh and dry biomass accumulation as previously mentioned. Similar results were obtained by Mogapi et al. (2013) in a study on the effect of chicken manure and commercial fertilizer on performance of Corchorus olitorious.

\section{Proximate and Mineral Composition}

Proximate composition as well as percentage nitrogen, phosphorus and potassium of Corchorus olitorius were significantly influenced by different types and rates of fertilizer application. Percentage ash content, crude protein, crude fat, fibre and nitrogen, phosphorus and potassium were significantly highest in plants treated with combination of both organic and inorganic fertilizer when compared to sole application of both fertilizer types alone and the control. It should be noted that the aforementioned nutrient attributes were significantly enhanced in plants treated with sole organic manure when compared with sole inorganic manure. Plants in the control plots showed the lowest values. Combined application of poultry manure and inorganic manure has been shown to integrate the beneficial attributes of both organic and inorganic fertilizers (Okunola et al., 2011). This is evident in the higher ash content, crude protein, crude fat and fibre as well as nitrogen, phosphorus and potassium uptake recorded in the combined application of both fertilizer as compared to either of the sole applications and the control. Significantly higher levels of the aforementioned nutrients in sole organic manure treated plant when compared to its sole inorganic fertilizer could be attributed to a better nutrient uptake in organic fertilizer plots than in inorganic fertilizer. These trends had earlier been reported by Mishra and Ganesh (2005) where they tested how different fertilizers affect the nutrient status of Abelmoschus esculentus.

\section{CONCLUSION}

The observed increase in growth, yield and nutrient composition of Corchorus olitorious plants treated with different combinations and rates of both organic and inorganic fertilizers over the control suggests that fertilizer application is highly necessary for a successful production of the plant. However, combined application of organic and inorganic fertilizers could be a better soil nutrient amendment when applied at a rate of $2000 \mathrm{kgha}^{-1} \mathrm{PM}+400$ $\mathrm{kgha}^{-1} \mathrm{NPK}$ and $2000 \mathrm{kgha}^{-1} \mathrm{PM}+600 \mathrm{kgha}^{-1} \mathrm{NPK}$ in the cultivation of Corchorus olitorious.

\section{REFERENCES}

Abd El-Mageed, Y.T., Gad El-Hak, S.H., Morsi, M.A. and Sadak, A.A. (2003). Response of tomato and cucumber to mulching colors and some treatments. 1-Tomatoes. Minia J.Agric. Res. and Develop. 20(2): 195-220.

Adediran, O.A., Ibrahim, H., Tolorunse, K.D. and Gana, U.I. (2015). Growth, Yield and Quality of Jute Mallow (Corchorus olitorius L.) as Affected by Different Nutrient Sources. International Journal of Agriculture Innovations and Research, 3(5):2319-1473.

Adejoro, S.A., Okunlola, A.I. and Fakanlu, G. (2011). Evaluation of Some Manure Types for the Growth and Yield of Watermelon in Southwestern Nigeria. Researcher. 3:393-395.

Akanbi, W.B. and Togun, A.O. (2002) . The influence of maize Stover compost and nitrogen fertilizer on growth, yield and nutrient uptake of Amaranth. Scientia Horticulturae 93: 1-9. 
Akanni, D.I., Ojeniyi, S.O. and Awodun, M.A. (2011). Soil properties, growth yield and nutrient content of Maize, Pepper and Amaranthus as influenced by organic and organomineral fertilizer, Journal of Agricultural Science and Technology, 1:1074-1078.

Aluko, O.A., Olanipekun, T.O., Olasoji, J.O., Abiola, I.O., Adeniyan, O.N., Olanipekun, S.O., Omenna E.C., Kareem K.O. and Douglas A.I., (2014). Effect of organic and inorganic fertilizer on the yield and Nutrient composition of jute mallow. Global Journal of Agriculture Research 2 (3):1-9.

Association of Analytical Chemist (AOAC). (2010). Official methods of analysis of AOAC International. Gaithersburg, MD, AOAC International.

Ayeni, L.S. (2008) Integrated application of cocoa pod ash and NPK fertilizer on soil chemical properties and yield of tomato, American-Eurasian Journal of Sustainable Agriculture 2(3):333-337.

Bermer, J.N. and Mulvalcy, C.W. (1982). Nitrogen total: Determination of total nitrogen by Micro-Kjeldahl method of soil analysis, chemical and microbiological properties part II. Am. Soc. Agron., 48:114-121.

Bray, R.H. and Kurtz, L.T. (1945). Determination of total and organic of phosphate in the soil. Soil Sci. J., 59:4549.

Ghoneim, I.M. and. El-araby, S.M., (2003). Effect of organic manure source and biofertilizer type on growth, productivity and chemical composition of jew's mallow (Corchorus olitorious 1.) Plants J. Agric. \& Env. Sci. 2(2): 88-105.

Ibedu, M.A., Unambra, R.P.A. and Udealor, A. (1988). Soil management strategies in relation to farming system development in Southwestern Agricultural zone of Nigeria. In: Adebanjo, A. (Ed.) Papers presented at the National Farming System Research Workshop, Jos, Plateau State, Nigeria Pp. 22-29.

Law-Ogbomo, K.E. and Osaigbovo, A.U. (2016).Growth and yield of ewedu (Corchorus olitorius) as influenced by food waste compost and inorganic fertilizer in a humid ultisol of southwestern Nigeria. Nigerian Journal of Agriculture, Food and Environment. 12(1): 80-84.

Law-Ogbomo, K.E. and Remison, S.U. (2007). The response of Dioscorea rotundata to NPK fertilizer in Edo State, Nigeria. Res. J. Agric. and Biological Sci. 3: 917-923.

Maclean, E.O. (1982). Methods of soil analysis. Part II. Am. Soc. Agron., 9:978-998.

Mahmoud, H.A.F., Sedera, F.A., Yousef, S.B.D. (2000). Effect of organic and inorganic fertilizers on onion crop. J. Agric Sci., Mansoura Univ. 25 (9): 5813-5829.

Masarirambi, M.T., Mbokazi, B.M., Wahome, P.K. and Oseni, T.O. (2012). Effects of kraal manure application rates on growth and yield of wild okra (Corchorus olitorius L.) in a sub-tropical environment. Asian Journal of Agricultural Sciences. 4(1): 89-95.

Mishra, R.K. and Ganesh, S. (2005). Effect of sources of nutrients on performance of okra (Abelmoschus esculentus (L.) Moench). Sri. Lankan Journal of Agricultural Science, 42: 52-57.

Mogapi E.M., Mathowa T., Mpofu, C., Stephen, N. and
Machacha, S. (2013). Effect of chicken manure and commercial fertilizer on performance of jute mallow (Corchorus olitorius). Agriculture and Biology Journal of North America, 4(6):617-622.

Mohamed, F.H. and S.M. Gabr. 2002. Effects of organic manure and chemical fertilization on the growth, yield and quality characteristics of strawberries. J. Agric. Sci. Mansoura Univ. 27 (1): 561-572.

Mylavarapus, R.S and Kennelley, D.E. 2002. UF//IFAS extension soil testing laboratory (ESTL): Analytical procedures and training manual. Institute of Food and Agricultural Science, University of Florida, Gainsville, USA Pp.55.

Odofin, A.J., Oladiran, J.A., Oladipo, J.A. and Wuya, E.P. (2011). Determination of evapotranspiration and crop coefficients for bush okra (Corchorus olitorius) in a subhumid area of Nigeria. African journal of Agricultural Research 6(17), Pp. 3949-3953.

Okunlola, A.I., Adejoro, S.A. and Fakanlu, G. (2011). Evaluation of Some Manure Types for the Growth and Yield of Watermelon in South-Western Nigeria. Researcher, 3(3):61-66.

Olaniyi, J.O., Akanbi, W.B., Oladiran, O.A. and Ilupeju, O.T. (2010) The effect of organomineral and inorganic fertilizers on the growth, fruit yield, quality and chemical compositions of Okra. Journal of Animal and Plant Sciences, 1:1135-1140.

Soil and Plant Analysis Council. (2000). Chapter 7. Major cations (potassium, calcium,magnesium, and sodium). In: Soil analysis handbook of reference methods. Soil and Plant Analysis Council, Inc., CRC Press, Boca Raton, FL.

Tolorunse, K.D., Ibrahim, H., Aliyu, N.C. and Oladiran, J.A. (2015). The Quality of Jute Mallow Seeds Exposed to Different Hot Water Steeping and Cooling protocols. American Journal of Experimental Agriculture 7(2):107-117.

Walkey, A. and Black, L.A. (1945). An examination of the oxidation methods for determining soil organic matter and proposed modification of the chronic and titration method. Soil Sci., 37:29-38. 
Table 3: Growth parameters of fertilizer treated Corchorus olitorius plants.

\begin{tabular}{|c|c|c|c|c|c|c|c|c|c|c|c|c|c|c|c|c|c|}
\hline & \multicolumn{3}{|c|}{ Plant Height (cm) } & \multicolumn{3}{|c|}{ Number of Leaves } & \multicolumn{3}{|c|}{ Stem Girth (cm) } & \multicolumn{3}{|c|}{ Leaf Area $\left(\mathrm{cm}^{2}\right)$} & \multicolumn{2}{|c|}{$\begin{array}{l}\text { Above-Ground } \\
\text { Weight (g) }\end{array}$} & \multicolumn{2}{|c|}{ Pod Mass (g) } & \multirow[t]{2}{*}{$\begin{array}{c}\text { Pod Number/ } \\
\text { plant }\end{array}$} \\
\hline & $\begin{array}{c}24 \\
\text { DAP }\end{array}$ & $\begin{array}{c}42 \\
\text { DAP } \\
\end{array}$ & $\begin{array}{c}56 \\
\text { DAP }\end{array}$ & $\begin{array}{c}24 \\
\text { DAP }\end{array}$ & $\begin{array}{c}42 \\
\text { DAP }\end{array}$ & $\begin{array}{c}56 \\
\text { DAP } \\
\end{array}$ & $\begin{array}{c}24 \\
\text { DAP } \\
\end{array}$ & $\begin{array}{c}42 \\
\text { DAP }\end{array}$ & $\begin{array}{c}56 \\
\text { DAP } \\
\end{array}$ & $\begin{array}{c}24 \\
\text { DAP }\end{array}$ & $\begin{array}{c}42 \\
\text { DAP }\end{array}$ & $\begin{array}{c}56 \\
\text { DAP }\end{array}$ & $\begin{array}{c}\text { Fresh } \\
\text { Weight }\end{array}$ & $\begin{array}{c}\text { Dry } \\
\text { Weight }\end{array}$ & $\begin{array}{c}\text { Fresh } \\
\text { Weight }\end{array}$ & $\begin{array}{c}\text { Dry } \\
\text { Weight }\end{array}$ & \\
\hline $\mathrm{T}_{1}$ & $28.37^{\mathrm{c}}$ & $55.53^{\mathrm{d}}$ & $76.96^{\mathrm{f}}$ & $19.00^{\mathrm{f}}$ & $43.55^{\mathrm{e}}$ & $69.22^{\mathrm{e}}$ & $1.34^{\mathrm{c}}$ & $2.37^{\mathrm{c}}$ & $3.52^{\mathrm{c}}$ & $10.07^{\mathrm{d}}$ & $19.25^{\mathrm{f}}$ & $33.09^{\mathrm{e}}$ & $24.73^{\mathrm{f}}$ & $6.39^{f}$ & $1.62^{\mathrm{d}}$ & $0.42^{\mathrm{d}}$ & $6.89^{\mathrm{e}}$ \\
\hline $\mathrm{T}_{2}$ & $31.32^{\mathrm{b}}$ & $58.02^{\mathrm{bc}}$ & $82.59^{\mathrm{cd}}$ & $20.99^{\text {ef }}$ & $43.22^{\mathrm{e}}$ & $69.78^{\mathrm{e}}$ & $1.40^{\mathrm{ab}}$ & $2.41^{\mathrm{ab}}$ & $3.62^{\mathrm{b}}$ & $10.10^{\mathrm{d}}$ & $20.10^{\mathrm{e}}$ & $33.67^{\mathrm{e}}$ & $26.63^{\mathrm{d}}$ & $6.69^{\mathrm{e}}$ & $1.68^{\mathrm{c}}$ & $0.47^{\mathrm{c}}$ & $8.45^{\mathrm{b}}$ \\
\hline $\mathrm{T}_{3}$ & $31.01^{\mathrm{b}}$ & $56.82^{\mathrm{c}}$ & $70.80^{\mathrm{g}}$ & $22.11^{\text {de }}$ & $49.11^{\mathrm{c}}$ & $74.11^{\text {cd }}$ & $1.39^{\mathrm{ab}}$ & $2.47^{\mathrm{a}}$ & $3.36^{\mathrm{e}}$ & $10.69^{c}$ & $20.36^{\mathrm{d}}$ & $33.54^{\mathrm{e}}$ & $22.30^{\mathrm{g}}$ & $6.04^{\mathrm{g}}$ & $1.52^{\mathrm{e}}$ & $0.35^{\mathrm{e}}$ & $4.22^{\mathrm{g}}$ \\
\hline $\mathrm{T}_{4}$ & $33.70^{\mathrm{a}}$ & $57.88^{\mathrm{b}}$ & $74.64^{\mathrm{f}}$ & $24.22^{\mathrm{bcd}}$ & $45.34^{\mathrm{e}}$ & $77.55^{b}$ & $1.41^{\mathrm{ab}}$ & $2.41^{\mathrm{ab}}$ & $3.42^{\mathrm{d}}$ & $10.89^{\mathrm{bc}}$ & $20.64^{c}$ & $33.80^{\mathrm{e}}$ & $24.54^{\mathrm{f}}$ & $6.27^{\mathrm{f}}$ & $1.54^{\mathrm{e}}$ & $0.39^{d}$ & $5.22^{\mathrm{f}}$ \\
\hline $\mathrm{T}_{5}$ & $35.09^{\mathrm{a}}$ & $59.50^{\mathrm{a}}$ & $75.60^{\mathrm{f}}$ & $27.22^{\mathrm{a}}$ & $47.89^{\mathrm{d}}$ & $72.11^{\mathrm{de}}$ & $1.42^{\mathrm{a}}$ & $2.44^{\mathrm{a}}$ & $3.44^{\mathrm{d}}$ & $11.21^{\mathrm{b}}$ & $21.43^{\mathrm{cd}}$ & $34.44^{\mathrm{d}}$ & $25.08^{\mathrm{e}}$ & $6.41^{\mathrm{f}}$ & $1.54^{\mathrm{e}}$ & $0.40^{\mathrm{d}}$ & $7.11^{\mathrm{d}}$ \\
\hline $\mathrm{T}_{6}$ & $30.68^{\mathrm{b}}$ & $54.59^{\mathrm{de}}$ & $80.02^{\text {de }}$ & $22.11^{\text {de }}$ & $47.89^{\mathrm{d}}$ & $75.56^{\mathrm{c}}$ & $1.39^{\mathrm{ab}}$ & $2.40^{\mathrm{b}}$ & $3.64^{\mathrm{a}}$ & $10.91^{\mathrm{bc}}$ & $21.86^{\mathrm{c}}$ & $36.97^{b}$ & $26.67^{\mathrm{d}}$ & $7.28^{\mathrm{d}}$ & $1.66^{\mathrm{cd}}$ & $0.48^{c}$ & $8.44^{\mathrm{b}}$ \\
\hline $\mathrm{T}_{7}$ & $33.56^{\mathrm{a}}$ & $58.26^{\mathrm{b}}$ & $84.75^{\mathrm{bc}}$ & $25.78^{\mathrm{abc}}$ & $49.56^{\mathrm{c}}$ & $77.78^{b}$ & $1.38^{\mathrm{b}}$ & $2.38^{\mathrm{bc}}$ & $3.59^{\mathrm{b}}$ & $11.66^{\mathrm{b}}$ & $22.33^{\mathrm{b}}$ & $37.07^{\mathrm{a}}$ & $27.82^{\mathrm{c}}$ & $7.56^{\mathrm{c}}$ & $1.70^{\mathrm{b}}$ & $0.49^{\mathrm{bc}}$ & $10.11^{\mathrm{a}}$ \\
\hline $\mathrm{T}_{8}$ & $34.28^{\mathrm{a}}$ & $59.97^{\mathrm{a}}$ & $87.30^{\mathrm{b}}$ & $26.89^{a}$ & $51.78^{b}$ & $78.45^{\mathrm{ab}}$ & $1.37^{\mathrm{b}}$ & $2.38^{\mathrm{bc}}$ & $3.59^{\mathrm{b}}$ & $11.96^{\mathrm{ab}}$ & $22.82^{b}$ & $37.77^{\mathrm{a}}$ & $28.09^{c}$ & $7.66^{\mathrm{c}}$ & $1.73^{\mathrm{ab}}$ & $0.52^{\mathrm{ab}}$ & $10.11^{\mathrm{a}}$ \\
\hline $\mathrm{T}_{9}$ & $31.15^{\mathrm{b}}$ & $53.86^{\mathrm{e}}$ & $79.73^{\mathrm{e}}$ & $23.89^{\mathrm{cd}}$ & $51.22^{\mathrm{bc}}$ & $74.22^{\mathrm{cd}}$ & $1.42^{\mathrm{a}}$ & $2.42^{\mathrm{ab}}$ & $3.66^{\mathrm{a}}$ & $11.92^{\mathrm{ab}}$ & $22.73^{b}$ & $35.59^{\mathrm{c}}$ & $26.94^{\mathrm{d}}$ & $7.51^{\mathrm{c}}$ & $1.67^{\mathrm{bc}}$ & $0.48^{\mathrm{b}}$ & $8.22^{\mathrm{c}}$ \\
\hline $\mathrm{T}_{10}$ & $33.30^{\mathrm{a}}$ & $54.78^{\mathrm{de}}$ & $86.96^{\mathrm{b}}$ & $26.22^{\mathrm{ab}}$ & $56.89^{a}$ & $76.22^{\mathrm{bc}}$ & $1.42^{\mathrm{a}}$ & $2.42^{\mathrm{ab}}$ & $3.60^{\mathrm{b}}$ & $12.59^{\mathrm{a}}$ & $23.39^{\mathrm{a}}$ & $36.57^{\mathrm{b}}$ & $28.55^{\mathrm{b}}$ & $7.74^{b}$ & $1.68^{\mathrm{c}}$ & $0.50^{\mathrm{b}}$ & $8.22^{\mathrm{c}}$ \\
\hline $\mathrm{T}_{11}$ & $34.81^{\mathrm{a}}$ & $59.48^{\mathrm{a}}$ & $90.10^{\mathrm{a}}$ & $27.44^{\mathrm{a}}$ & $58.78^{\mathrm{a}}$ & $80.11^{\mathrm{a}}$ & $1.41^{\mathrm{ab}}$ & $2.41^{\mathrm{ab}}$ & $3.66^{\mathrm{a}}$ & $12.82^{\mathrm{a}}$ & $23.88^{\mathrm{a}}$ & $37.54^{\mathrm{a}}$ & $29.49^{\mathrm{a}}$ & $7.95^{\mathrm{a}}$ & $1.75^{\mathrm{a}}$ & $0.55^{\mathrm{a}}$ & $9.56^{\mathrm{a}}$ \\
\hline Control & $24.17^{\mathrm{d}}$ & $39.27^{\mathrm{f}}$ & $48.20^{\mathrm{h}}$ & $15.27^{\mathrm{g}}$ & $30.89^{\mathrm{f}}$ & $45.44^{\mathrm{f}}$ & $1.09^{\mathrm{d}}$ & $1.66^{\mathrm{d}}$ & $2.62^{\mathrm{f}}$ & $9.29^{\mathrm{e}}$ & $17.11^{\mathrm{g}}$ & $26.98^{\mathrm{f}}$ & $18.87^{\mathrm{h}}$ & $5.21^{\mathrm{h}}$ & $1.28^{\mathrm{f}}$ & $0.31^{\mathrm{f}}$ & $4.22^{\mathrm{g}}$ \\
\hline
\end{tabular}

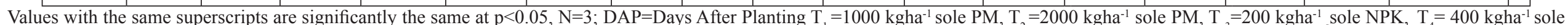

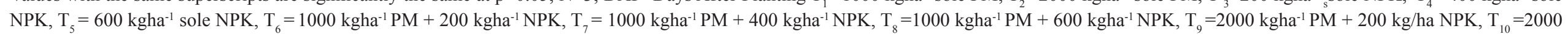
$\mathrm{kgha}^{-1} \mathrm{PM}+400 \mathrm{kgha}^{-1} \mathrm{NPK} \mathrm{T}_{11}=2000 \mathrm{kgha}^{-1} \mathrm{PM}+600 \mathrm{kgha}^{-1} \mathrm{NPK}$ 
Table 4: Nutrient composition of fertilizer treated Corchorus olitorius plants.

\begin{tabular}{l|l|l|l|l|l|l|l|l|l|l}
\hline \multirow{2}{*}{ Treatment } & $\mathbf{A S H}$ & $\mathbf{M} / \mathbf{C}$ & $\mathbf{C} / \mathbf{P}$ & $\mathbf{C} / \mathbf{F B}$ & $\mathbf{C} / \mathbf{F T}$ & $\mathbf{C H O}$ & $\mathbf{N}$ & $\mathbf{P}$ & $\mathbf{K}$ \\
\cline { 2 - 9 } & \multicolumn{7}{|c}{ Percentage (\%) } \\
\hline $\mathrm{T}_{1}$ & $10.29^{\mathrm{d}}$ & $10.58^{\mathrm{g}}$ & $1.29^{\mathrm{d}}$ & $33.10^{\mathrm{b}}$ & $1.87^{\mathrm{b}}$ & $42.89^{\mathrm{cd}}$ & $205.60^{\mathrm{e}}$ & $92.40^{\mathrm{c}}$ & $82.45^{\mathrm{g}}$ \\
$\mathrm{T}_{2}$ & $10.89^{\mathrm{a}}$ & $10.75^{\mathrm{f}}$ & $1.44^{\mathrm{b}}$ & $36.17^{\mathrm{a}}$ & $1.93^{\mathrm{a}}$ & $38.83^{\mathrm{e}}$ & $229.60^{\mathrm{c}}$ & $99.79^{\mathrm{b}}$ & $89.79^{\mathrm{f}}$ \\
$\mathrm{T}_{3}$ & $9.41^{\mathrm{f}}$ & $11.12^{\mathrm{d}}$ & $1.01^{\mathrm{f}}$ & $31.60^{\mathrm{c}}$ & $1.65^{\mathrm{e}}$ & $45.23^{\mathrm{b}}$ & $160.10^{\mathrm{f}}$ & $79.31^{\mathrm{e}}$ & $72.52^{\mathrm{j}}$ \\
$\mathrm{T}_{4}$ & $9.51^{\mathrm{e}}$ & $11.21^{\mathrm{cd}}$ & $1.11^{\mathrm{e}}$ & $31.89^{\mathrm{c}}$ & $1.62^{\mathrm{g}}$ & $44.68^{\mathrm{b}}$ & $176.80^{\mathrm{e}}$ & $87.39^{\mathrm{d}}$ & $78.68^{\mathrm{i}}$ \\
$\mathrm{T}_{5}$ & $9.56^{\mathrm{f}}$ & $11.44^{\mathrm{a}}$ & $1.30^{\mathrm{d}}$ & $32.95^{\mathrm{bc}}$ & $1.60^{\mathrm{f}}$ & $43.15^{\mathrm{c}}$ & $208.0^{\mathrm{e}}$ & $89.98^{\mathrm{cd}}$ & $80.92^{\mathrm{h}}$ \\
$\mathrm{T}_{6}$ & $10.43^{\mathrm{c}}$ & $10.81^{\mathrm{f}}$ & $1.32^{\mathrm{d}}$ & $33.37^{\mathrm{b}}$ & $1.66^{\mathrm{f}}$ & $42.43^{\mathrm{cd}}$ & $209.60^{\mathrm{e}}$ & $93.59^{\mathrm{c}}$ & $91.56^{\mathrm{e}}$ \\
$\mathrm{T}_{7}$ & $10.39^{\mathrm{c}}$ & $10.97^{\mathrm{e}}$ & $1.35^{\mathrm{cd}}$ & $33.43^{\mathrm{b}}$ & $1.73^{\mathrm{d}}$ & $41.64^{\mathrm{d}}$ & $215.20^{\mathrm{d}}$ & $98.42^{\mathrm{b}}$ & $94.16^{\mathrm{d}}$ \\
$\mathrm{T}_{8}$ & $10.26^{\mathrm{d}}$ & $11.15^{\mathrm{d}}$ & $1.43^{\mathrm{c}}$ & $33.54^{\mathrm{b}}$ & $1.78^{\mathrm{c}}$ & $41.85^{\mathrm{d}}$ & $228.0^{\mathrm{c}}$ & $99.03^{\mathrm{b}}$ & $99.73^{\mathrm{c}}$ \\
$\mathrm{T}_{9}$ & $10.89^{\mathrm{a}}$ & $11.22^{\mathrm{c}}$ & $1.41^{\mathrm{c}}$ & $35.53^{\mathrm{a}}$ & $1.70^{\mathrm{d}}$ & $39.26^{\mathrm{e}}$ & $225.60^{\mathrm{cd}}$ & $92.37^{\mathrm{c}}$ & $93.98^{\mathrm{d}}$ \\
$\mathrm{T}_{10}$ & $10.58^{\mathrm{b}}$ & $11.27^{\mathrm{c}}$ & $1.48^{\mathrm{b}}$ & $35.65^{\mathrm{a}}$ & $1.83^{\mathrm{b}}$ & $39.21^{\mathrm{e}}$ & $236.80^{\mathrm{b}}$ & $93.10^{\mathrm{c}}$ & $104.22^{\mathrm{b}}$ \\
$\mathrm{T}_{11}$ & $10.54^{\mathrm{b}}$ & $11.33^{\mathrm{b}}$ & $1.55^{\mathrm{a}}$ & $35.01^{\mathrm{a}}$ & $1.96^{\mathrm{a}}$ & $39.64^{\mathrm{e}}$ & $247.20^{\mathrm{a}}$ & $105.56^{\mathrm{a}}$ & $111.93^{\mathrm{a}}$ \\
Control & $7.35^{\mathrm{g}}$ & $10.11^{\mathrm{h}}$ & $0.76^{\mathrm{g}}$ & $29.60^{\mathrm{h}}$ & $1.45^{\mathrm{h}}$ & $50.74^{\mathrm{a}}$ & $121.80^{\mathrm{g}}$ & $64.58^{\mathrm{f}}$ & $57.02^{\mathrm{k}}$ \\
\hline
\end{tabular}

Values with the same superscripts are significantly the same at $\mathrm{p}<0.05, \mathrm{~N}=3$; DAP=Days After Planting $\mathrm{T}_{1}=1000 \mathrm{kgha}^{-1}$ sole $^{\mathrm{PM}}$, $\mathrm{T}_{2}$ $=2000 \mathrm{kgha}^{-1}$ sole PM, T $3=200 \mathrm{kgha}^{-1}{ }_{\mathrm{s}}$ sole NPK, $\mathrm{T}_{4}=400 \mathrm{kgha}^{-1}$ sole NPK, $\mathrm{T}_{5}=600 \mathrm{kgha}^{-1}$ sole NPK, $\mathrm{T}_{6}=1000 \mathrm{kgha}^{-1} \mathrm{PM}+200 \mathrm{kgha}^{-1}$ $\mathrm{NPK}, \mathrm{T}_{7}=1000 \mathrm{kgha}^{-1} \mathrm{PM}+400 \mathrm{kgha}^{-1} \mathrm{NPK}, \mathrm{T}_{8}=1000 \mathrm{kgha}^{-1} \mathrm{PM}+600 \mathrm{kgha}^{-1} \mathrm{NPK}, \mathrm{T}_{9}=2000 \mathrm{kgha}^{-1} \mathrm{PM}+200 \mathrm{~kg} / \mathrm{ha} \mathrm{NPK}, \mathrm{T}_{10}=2000$ $\mathrm{kgha}^{-1} \mathrm{PM}+400 \mathrm{kgha}^{-1} \mathrm{NPK} \mathrm{T}_{11}=2000 \mathrm{kgha}^{-1} \mathrm{PM}+600 \mathrm{kgha}^{-1} \mathrm{NPK}$. 